\title{
Peranan Geomorfologi Dalam Kajian Kerentanan Air Bawah Tanah Karst
}

\author{
Oleh : Tjahyo Nugroho Adji \\ Kelompok Studi Karst, Fakultas Geografi UGM, Yogyakarta, 55281
}

Telp. :62-8122967492; email:adji_bruang@yahoo.com

\begin{abstract}
Abstrak
Karst merupakan daerah berbatuan gamping dan dikenal sebagai kawasan yang unik secara geomorfologi karena bentuklahan permukaannya yang "cantik" dan spesifik yang tidak dapat ditemukan pada unit geomorfologi yang lain. Meskipun demikian, karena sifatnya yang mudah larut dalam air, topografi karst memilki sistem air bawah permukaan yang dominan berupa lorong-lorong solusional dan sangat rentan terhadap degradasi, terutama terhadap kontaminasi air bawah tanah. Hal ini disebabkan karena cepatnya aliran air serta minimnya mekanisme filter pada loronglorong sistem bawah tanah. Tulisan ini membahas bagaimana metode-metode klasifikasi yang sudah dikembangkan untuk menilai tingkat kerentanan terhadap pencemaran air di kawasan karst serta mengkaji peran parameter geomorfologi yang digunakan pada metode-metode tersebut. Tulisan ini akan didahului dengan sedikit deskripsi mengenai geomorfologi karst dan kemudian banyak mengetengahkan contoh-contoh cara mengklasifikasikan kerentanan air bawah tanah karst, dan memberi justifikasi tentang andil parameter-parameter geomorfologi yang digunakan.
\end{abstract}

Kata kunci : metode, kerentanan karst, geomorfologi

\section{Pendahuluan}

Membahas geomorfologi daerah karst tidak bisa lepas dari batuan dominannya yaitu batuan gamping (White,1988). Batuan gamping adalah batuan sedimen yang biasanya didominasi oleh kalsium karbonat dalam bentuk mineral kalsit (Ford and Williams, 1992). Selanjutnya, oleh Dreybrodt (1988) dijelaskan bahwa proses kimia yang dominan terjadi di batuan gamping adalah proses pelarutan yang dimulai dari jatuhnya air hujan yang jenuh dengan gas karbondioksida dan membentuk kesetimbangan dalam air yang asam sebagai $\mathrm{H}_{2} \mathrm{CO}_{3}$ (asam karbonat). Karena sifatnya yang asam, maka air tersebut akan dengan mudah melarutkan batuan gamping dan meninggalkan kation kalsium dan anion bikarbonat terlarut dalam air. Karena sifatnya yang demikian, maka di daerah berbatuan gamping lebih didominasi oleh sistem aliran bawah permukaan dibandingkan dengan sistem permukaan. Sementara itu, proses pelarutan tersebut, jika sudah mencapai tahap tertentu akan memunculkan tipe topografi yang lain dari yang biasa ditemukan di tempat lain, yang dikenal sebagai tipe topografi karst (Alpha, et. al, 2002).

Istilah "karst" mula-mula diambil dari suatu nama tempat Krs di Slovenia (sekarang terletak di baratlaut Yugoslavia), merupakan suatu tipikal dari lahan gersang yang berbatu (Short and Blair, 1986). Beberapa sejarawan juga mengatakan wilayah tersebut dekat dengan kota Trieste, Italia. Dari tipikal kata Indo-Eropa, "kar" atau "karra" atau dalam bahasa Italia adalah "carso" yang berarti batu kemudian berevolusi menjadi kars atau kras (Bahasa Jerman). Pada dunia pendidikan, istilah karst pertama kali dipakai dalam bidang ilmu kebumian di sekolah-sekolah geografi dan geologi di Wina Austria, sekitar pertengahan abad 19 (Sweeting, 1972; Ford and 


\section{Citation: Gunung Sewu, Indonesian Cave and Karst J ournal, Vol 2, No 1, April 2006}

Williams, 1992). Beberapa ahli menggunakan karst sebagai istilah untuk medan dengan batuan gamping yang dicirikan oleh drainase permukaan yang langka, solum tanah tipis dan hanya setempat-setempat, terdapatnya cekungan-sekungan tertutup (dolin), dan terdapatnya sistem drainase bawah tanah (Summerfield, 1991). Ford dan Wiliam (1992) mendefinisikan secara lebih umum sebagai medan dengan karakteristik hidrologi dan bentuklahan yang diakibatkan oleh kombinasi dari batuan mudah larut dan mempunyai porositas sekunder yang berkembang baik.

Bahkan, menurut Alpha, et. al, (2002) yang mengembangkan model simulasi perkembangan topografi karst di daerah tropis, mendeskripsikan bahwa lapisan batugamping di daerah tropis lebih tebal dan secara geomorfologis menghasilkan bentuk lahan yang lebih spektakuler berupa bukit-bukit yang berbentuk kerucut dengan lembah-lembah yang sempit. Bentukan morfologi lain yang menjadi perhatian adalah bentukan morfologi mikro karst yaitu pinnacle/lapies/karren yang mempunyai berbagai macam ukuran dan menambah keunikan geomorfologi karst di daerah tropis.

\section{Kerentanan Kawasan Karst}

Kerentanan lingkungan menjadi kata yang dikenal dan sering muncul pada sekitar tahun 1990-an, termasuk kata kerentanan karst (Leibundgut, 1998). Menurutnya, topik penelitian tentang kerentanan akuifer karst muncul ke permukaan akibat perkembangan sistem drainase karst yang memungkinkan akufer karst memiliki tingkat kerentanan yang tinggi. Selanjutnya, oleh Gunn (1986) kerentanan karst didefinisikan pada penurunan potensi sumberdaya alam karst baik itu secara kualitas dan kuantitas.

Leibundgut (1998) selanjutnya menjelaskan bahwa tinggginya tingkat kerentanan terhadap pencemaran airtanah di kawasan karst dibandingkan dengan kawasan lain lebih disebabkan karena tingginya nilai permeabilitas sekunder hasil proses pelarutan yang menghasilkan banyaknya jaringan air bawah tanah berupa lorong-lorong dan saluran-saluran baik yang berukuran besar (conduit) dan kecil (fissure) serta minimnya proses penyaringan (filtering) bahan pencemar. Kemudian dijelaskan pula oleh Foster (1987), bahwa pada umumnya, topografi karst mempunyai lapisan tanah yang sangat tipis, sehingga penyaringan dan peruraian (breakdown) mikroorganisme dan pencemar baik secara fisika dan kimia yang biasanya berjalan sangat efektif pada lapisan tanah, menjadi sangat kecil. Bahkan, menurut Smith (1993), pada daerah karst dengan lapisan tanah yang tebal tapi terdapat banyak sungai permukaan yang masuk ke dalam tanah (sinking stream), maka peranan tanah sebagai filter tetap saja terabaikan (tidak ada). Lebih jauh lagi juga dikatakan bahwa jika daerah hulu kawasan karst tidak diproteksi secara baik, maka dapat dikatakan bahwa pencemaran pasti terjadi di daerah hilir. Secara singkat dapat dikatakan bahwa kerentanan karst sangat nyata dan mudah sekali terjadi dan untuk memprediksi distribusi kerentananannya bukan merupakan suatu pekerjaan yang mudah. Selanjutnya, ilustrasi kerentanan akuifer karst diilustrasikan pada Gambar 1. 


\section{Citation: Gunung Sewu, Indonesian Cave and Karst J ournal, Vol 2, No 1, April 2006}

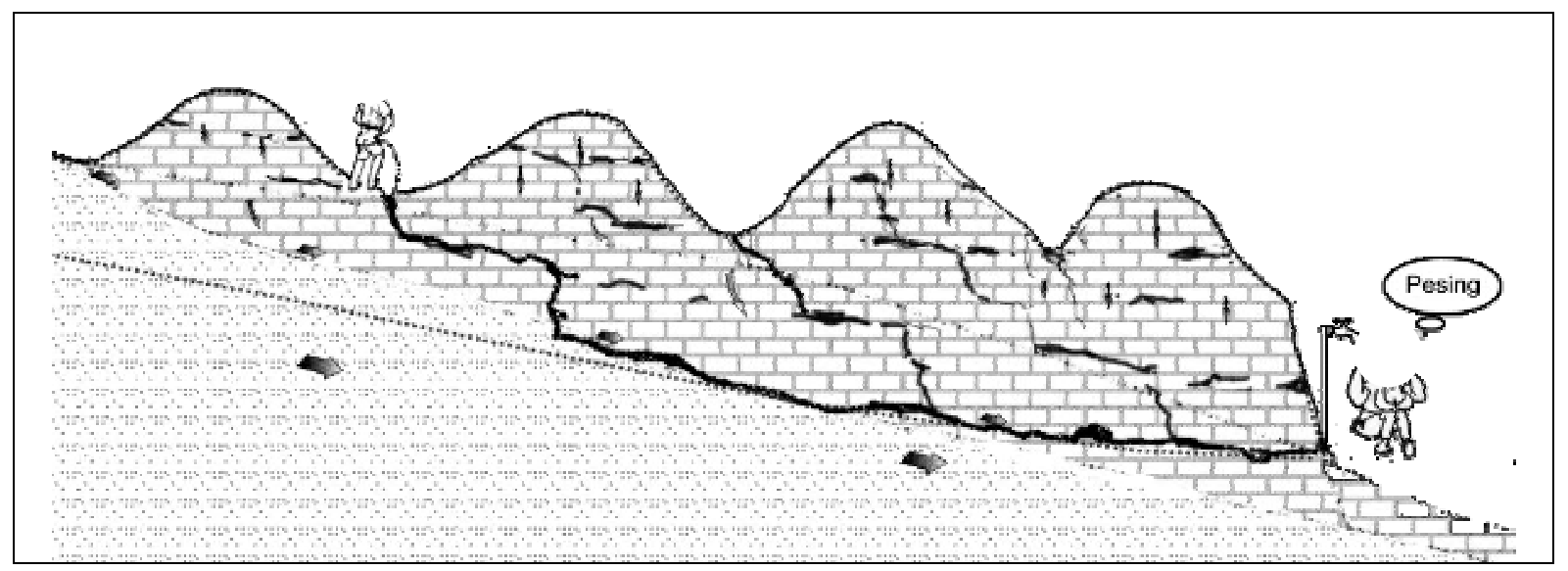

Gambar 1. Kerentanan Akifer Karst Terhadap Bahan Pencemar (Haryono, 2004).

Lebih jauh lagi, menurut Leibundgut (1998), secara detail kerentanan (vulnerability) di daerah karst dapat dikelompokkan menjadi dua yaitu (1) kerentanan intrinsik (intrinsic permeability), yaitu kerentanan yang diakibatkan oleh sifat daerah karst itu sendiri dan (2) kerentanan spesifik (spesific vulnerability), yaitu kerentanan akibat ancaman aktual seperti limbah domestik, penggunaan lahan, dll. Menurut Quinlan et al. (1991), tingkat kerentanan intrinsik tergatung dari faktor-faktor sebagai berikut :

- Ketersediaan lapisan tanah yang sangat penting sebagai zona filtering bahan pencemar

- Karakteristik sifat infiltrasi (diffuse). Pada karst yang tertutup lebat oleh vegetasi, tingkat bahya rentannya rendah, sementara jika banyak sungai yang masuk ke dalam tanah (point recharge), maka tingkat bahaya kerentanannya akan tinggi

- Perkembangan zone epikarst. Epikarst adalah zone dekat permukaan yang merupakan tempat utama penyimpan airtanah

- Perkembangan topografi dan sistem karst, lebih dominan fissure/diffuse (loronglorong kecil) atau conduit (lorong-lorong besar).

Keempat faktor tersebut saling terkait dan bervariasi secara spasial pada suatu kawasan karst, dan terkait juga dengan sistem aliran dan kecepatan air mengalir akan sangat menentukan dalam penentuan tingkat bahaya kerentanan karst.

\section{Metode-Metode Penentuan Kerentanan Karst}

\section{Metode EPIK}

Metode EPIK merupakan metode yang sampai saat ini diangap paling representatif untuk memetakan distribusi kerentanan akuifer karst terhadap pencemaran. Metode ini pertama kali dikembangkan oleh Doerflinger and Zwahlen (1998) dari Centre of Hydrogeology, University of Neuchatel, Swiss. EPIK adalah multi paramater metode yaitu $\mathrm{E}=$ Epikarst, $\mathrm{P}=$ Protective Cover, $\mathrm{I}=\mathrm{Infiltration}$ dan $\mathrm{K}=\mathrm{Karst}$ Network yang merupakan faktor pembobot terhadap kelas kerentanan suatu kawasan karst. Metode ini pada prinsipnya adalah suatu metode yang dikenal sebagai Weighted Index Overlay by GIS yang merupakan metode berbasis SIG dengan cara overlay dan skoring untuk menentukan zonasi kerentanan karst pada suatu wilayah. 
Parameter pertama adalah Epikarst (E). Epikarst, atau lebih dikenal sebagai subcutaneous zone adalah lapisan sedikit dibawah solum tanah yang memiliki nilai permeabilitas yang sangat tinggi. Epikarst biasanya mempunyai ketebalan antara 0,5 s.d. 2 meter, tapi pada beberapa kawasan karst ada yang bisa memcapai kedalaman 5 s.d. 10 meter. Epikarst merupakan lapisan yang paling penting dalam stratigrafi akuier karst karena merupakan media penyimpan air sebelum diatuskan ke sungai bawah tanah melalui lorong-lorong baik itu diffuse atupun conduit (Ford and Williams, 1989). Setelah zone epikarst ini secara vertikal kebawah sebenarnya simpanan air berkurang karena berkurangnya porositas/permeabilitas sekunder batuan (Gambar 2).

Selanjutnya, kriteria kondisi Epikarst dibagi lagi menjadi 3 kelas yaitu $E_{1}$ (paling rentan), $E_{2}$ (menengah), dan $E_{3}$ (tidak rentan). Yang menarik adalah, penentuan kelas kondisi Epikarst ni menurut Doerflinger and Zwahlen (1998) harus didasarkan pada studi kondisi geomorfologi kawasan karst sebelumnya sebagai penciri zonasi Epikarst. Kelas $\mathrm{E}_{1}$ yang paling rentan dicirikan oleh geomorfologi yang banyak memilki lembah-lembah dengan lobang ponor di dasar lembah, banyaknya proses runtuhan pada dinding lembah, dominasi mikromorfologi karst seperti karren/lapies, terdapatnya doline yang cukup banyak, serta rekahan yang cukup banyak pada morfologi permukaan. Sementara itu kelas $E_{2}$ (kerentanan menengah) dicirikan dengan banyaknya lembah kering dan doline tanpa kemunculan rekahan dan point recharge. Terakhir, kelas $E_{3}$ (kerentanan rendah) cukup dicirikan oleh sedikitnya sungai permukaan yang masuk ke dalam tanah. Kemudian, oleh Doerflinger and Zwahlen (1998) dijelaskan pula bahwa untuk menentukan kelas kerentanan zona epikarst cukup dilakukan dengan melakukan pemetaan geomorfologi dan penggunaan foto udara. Skala obyek yang biasa digunakan adalah 1;5000, 1: 1:10000, dan 1:25000 tergantung kedetailan informasi yang diinginkan.

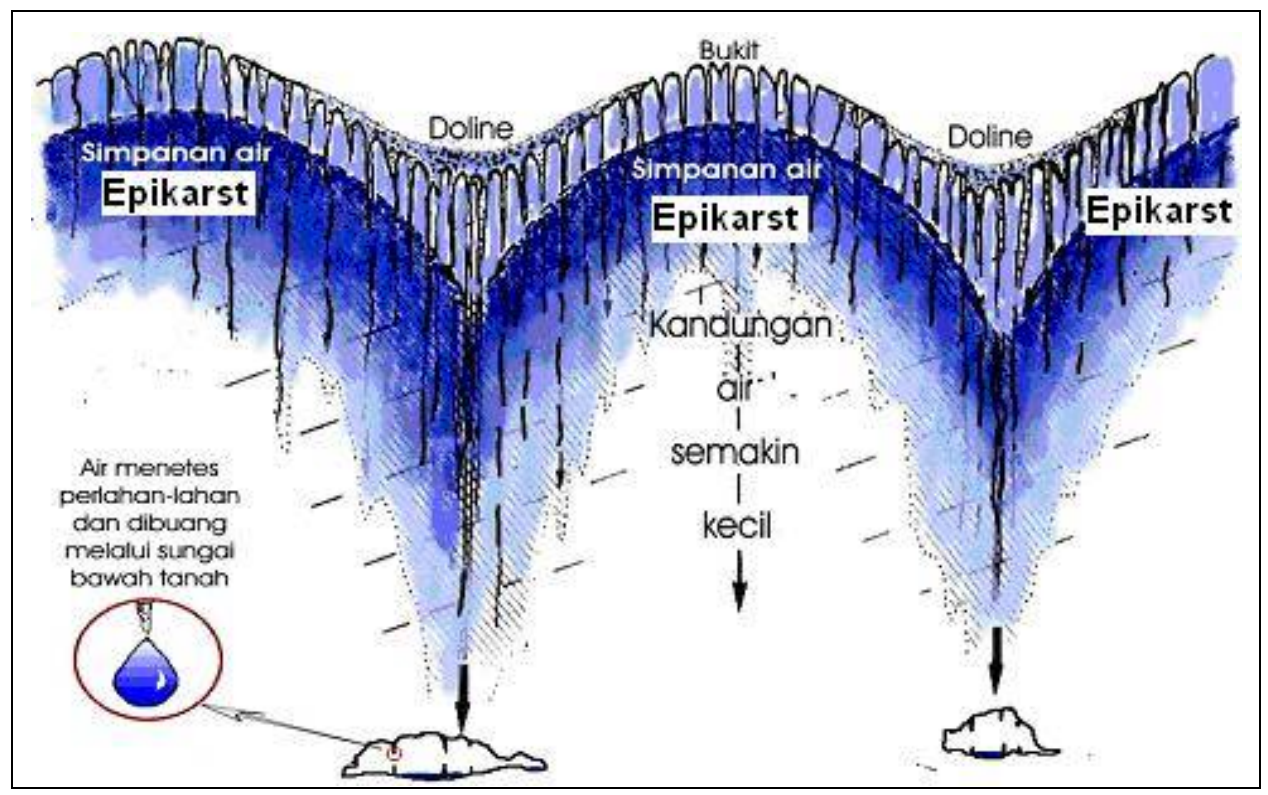

Gambar 2. Konsep Epikarst sebagai reservoir Karst (Haryono, 2004)

Parameter yang kedua adalah $\mathrm{P}$ atau Protective Cover, atau secara lebih khususnya lagi adalah ketebalan tanah yang berfungsi sebagai penyaring bahan 
pencemar sebelum masuk ke akuifer karst. Penentuan tebal tanah juga dapat didekati dengan zonasi geomorfologi mengingat ada beberapa paramater geomorfologi yang mengontrol genesa tanah seperti lereng, jenis batuan induk, dan proses geomorfologi.

Parameter selanjutnya adalah I atau Infiltration Condition. Besar kecilnya I tergantung dari jenis tanah dam morfologi medan. Jenis tanah yang sama dengan kelerengan yang berbeda akan menghasilkan nilai kapasitas infiltrasi yang berbeda pula. Akibatnya, besar kecilnya nilai infiltrasi juga tergantung dari morfologi medan dan juga sifat dari tanah yang terbentuk. Masih menurut Doerflinger and Zwahlen (1998), penentuan besar kecilnya nilai I biasanya didekati dengan survey untuk menentukan Zones of Concentrated Infiltration. Zone pusat infiltrasi besar ini biasanya terkait juga dengan paramater geomorfologi seperti kelerengan dan penggunaan lahan serta kemungkinan adanya sungai yang tertelan (shallow hole/ponor) yang bisa didekati dengan interpretasi peta topografi.

Paramater yang terakhir adalah $\mathrm{K}$ atau Karstic Network yang menurut Doerflinger and Zwahlen (1998) biasa didekati dengan analisis hidrograf banjir dan kemograf pada mata air-mata air, dan juga dengan menggunakan water tracing. Jika nilai $\mathrm{K}$ tinggi dapat diartikan bahwa tingkat bahaya kerentanannya juga tinggi karena conduit sudah berkembang dan membentuk jaringan yang dominan daripada lorong yang bersifat diffuse (kecil).

\section{Metode Attributed Sinks}

Metode ini dikembangkan oleh Plan et al. (2003) dari Department of Geological Sciences, University of Vienna, Austria. Pada awal tulisannya, Plan et al. (2003) mengutip pernyataan dari Goldscheider et al. (2000) dan Doerflinger and Zwahlen (1999) yang menjelaskan bahwa morfologi dan karakteristik proses infiltrasi sangat penting dalam rangka mengkaji kerentanan air bawah tanah karst. Selanjutnya, dijelaskan pula bahwa cekungan karst (sink) (Gambar 3) merupakan salah satu ciri geomorfologi karst yang harus paling sering diperhatikan ketika melakukan kajian kerentanan akuifer karst karena beberapa faktor berikut ini :

- Air hujan yang jatuh akan mengumpul pada cekungan karst yang secara langsung masuk ke sistem conduit melalui ponor

- Pada cekungan karst (sink), maka bahan pencemar tidak disaring melalui zona tanah dan akan masuk ke sistem drainase bawah tanah secara cepat tanpa proses pemurnian kembali (purification).

- Tiap-tiap sink memiliki daerah tangkapan yang sebanding dengan jumlah air yang akan masuk ke dalam tanah.

- Topografi zona air bawah permukaan pada zone epikarst akan selaras dengan topografi pemukannya.

Dilihat dari nama metodenya (Attributed Sinks), maka hal yang paling penting dilakukan adalah menginventarisasi keberadaan geomorfologi lembah-lembah karst (Gambar 3). 


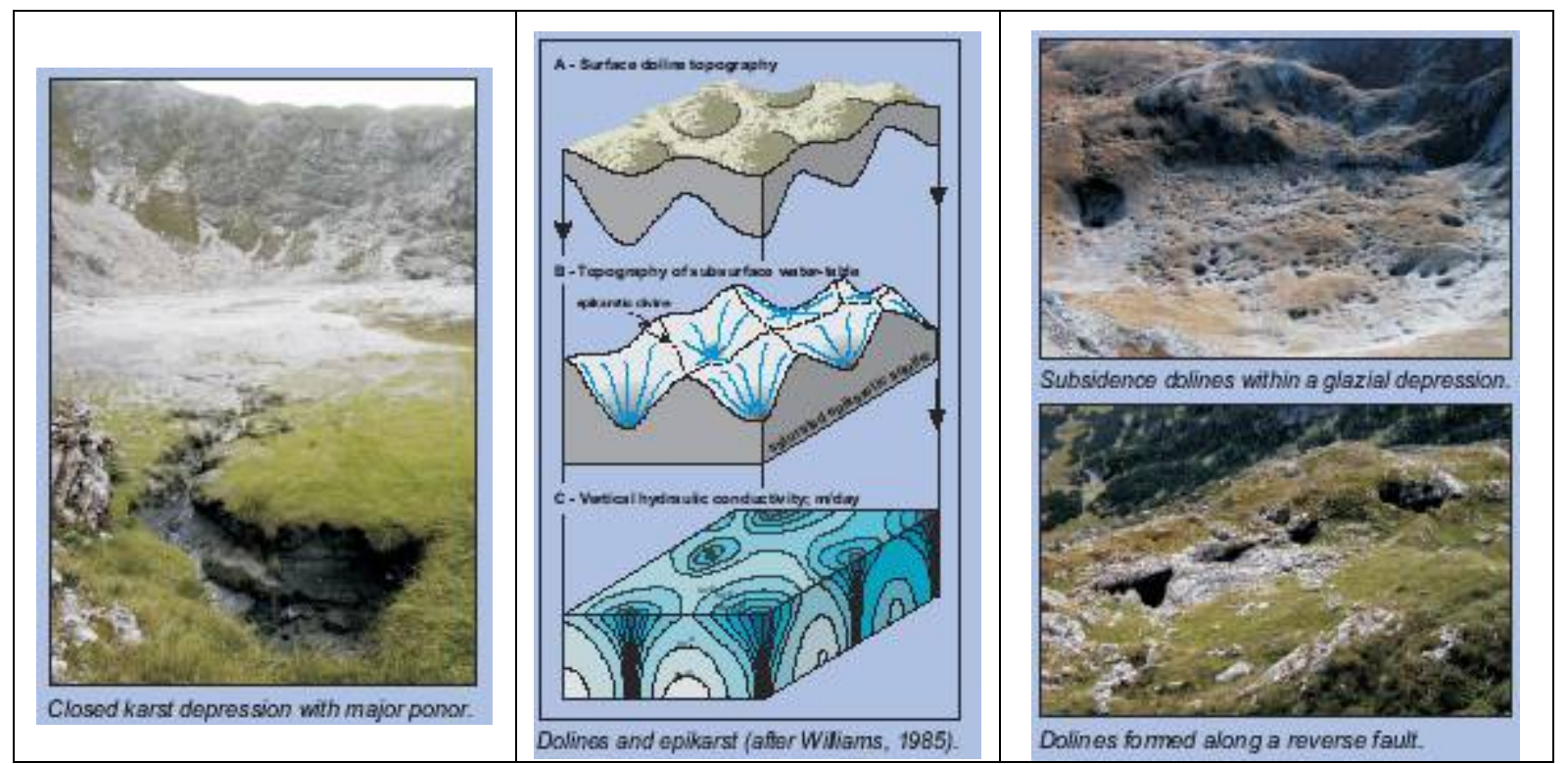

Gambar 3. Cekungan Karst Sebagai Jalan Masuknya Bahan Pencemar (Plan et al., 2003)

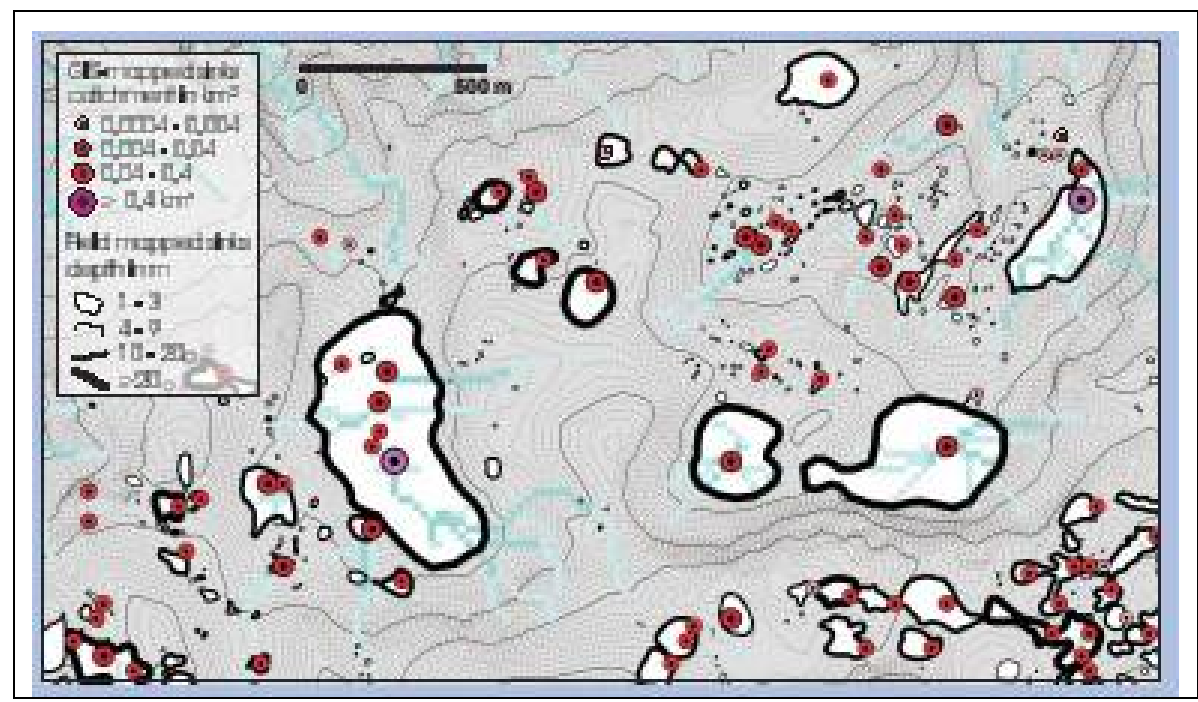

Gambar 4. Identifikasi Cekungan Karst dan Ponor (Plan et al., 2003)

Metode ini selanjutnya sudah dicoba di kawasan karst Alpen Utara yang mempunyai fenomena geomorfologi karst yang kompleks seperti doline, lapies/karren, polje, ponor, mata air, yang poisisinya sudah dipetakan secara sistematis, termasuk keberadaan 900 gua di kawasan ini. Inti dari metode ini sebenarnya adalah memetakan konsentrasi lembah-lembah karst dan kemungkinan adanya ponor didalamnya, seperti yang disajikan pada Gambar 4. 


\section{Citation: Gunung Sewu, Indonesian Cave and Karst J ournal, Vol 2, No 1, April 2006}

Selanjutnya, untuk memodelkannya secara spasial dapat dibantu oleh software GIS untuk :

- Membuat profil DEM (Digital Elevation Model)

- Menghitung luasan daerah tangkapan hujan masing-masing cekungan (sinks)

- Cek lapangan, untuk membedakan mana cekungan karst dan mana yang bukan

Terakhir, dilakukan pengkelasan atas dasar keberadaan dan karakteristik geomorfologi cekungan-cekungan karst yang diperoleh dari model, dan kemudian dibedakan menjadi 4 kelas kerentanan pencemaran karst yaitu :

- Kelas 1 (ringan) : Daerah dengan kepadatan sinks yang jarang dengan dominasi aliran permukaan (Gambar 5-hijau)

- Kelas 2 (agak berat) : Daerah dengan sebaran sinks kecil-kecil, cukup banyak, ada aliran permukaan tapi tidak banyak (Gambar 5-abu-abu)

- Kelas 3 (berat) : Daerah dengan sedikit cekungan tetapi berukuran sangat besar (diameter beberapa ratus meter). (Gambar 5-biru)

- Kelas 4 (sangat berat) : Daerah dengan banyak polje, cekungan, dan ponorponor ditengahnya dengan distribusi yang banyak (Gambar 5-merah).

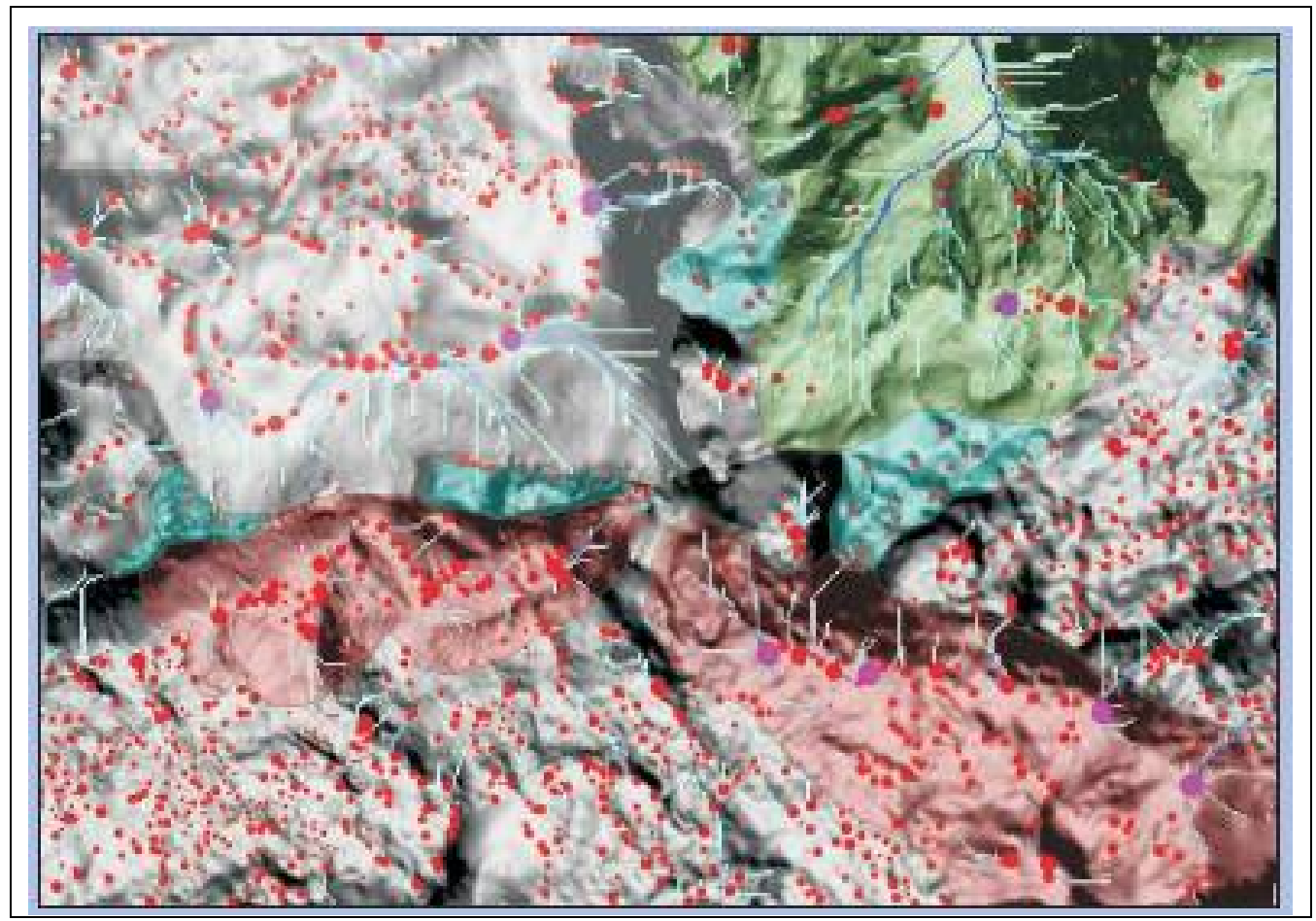

Gambar 4. Identifikasi Kelas Kerentanan Atas Dasar Keberadaan Cekungan Karst (Plan, et al. 2003)

\section{Metode VURAAS}

Metode ini dikembangkan oleh Cichocki and Zojer (2005) yaitu metode mengevaluasi kerentanan pada suatu kawasan karst berbasis GIS. VURAAS adalah 
suatu akronim yang merupakan kepanjangan dari Vulnerability and Risk Analysis in Alpine Aquifer System (metode ini dikembangan pertama kali pada kawasan karst Alpine). VURAAS menurut Cichocki and Zojer (2005) digunakan untuk merekonstruksi aliran air yang terinfiltrasi dari permukaan yang kemudian menuju akuifer karst. Uruturutan parameter yang dianalisis adalah input $(P)$, kemudian infiltrasi $(I)$, exfiltrasi $(E)$ dan terakhir validasi (A). Faktor E dianggap merupakan cara untuk memvalidasi faktor I. Jalur aliran yang akan direkonstruksi oleh VURAAS akan diklarifikasi secara obyektif dengan bantuan interpretasi data hidrogeologi, dan water tracing (isotop, hidrokimia, dII) pada mataair, aliran permukaan yang masuk ke akuifer karst, dan air yang terinfiltrasi ke dalam tanah.

\section{a. Faktor I nput (P)}

Faktor P adalah menunjukkan besarnya hujan efektif dan faktor-faktor lainnya, yang nantinya merupakan nilai awal dari parameter-parameter lainnya, terutama faktor I dan E. Untuk menentukan besarnya nilai P, menurut Cichocki and Zojer (2005), harus mempertimbangkan beberapa hal dan yang terpenting adalah :

- $\quad$ kelerengan untuk menentukan besarnya aliran permukaan

- geomorfologi permukaan (perkembangan karst) untuk mengetahui sejauh mana hujan dan runoff akan masuk kedalam tanah

Dari faktor ini sangat jelas sekali bahwa pengetahuan geomorfologi sangat penting untuk mendefinisikan magnitudo faktor $\mathrm{P}$ disamping faktor lain seperti tutupan lahan untuk evapotranspirasi dan kondisi klim global. Sehingga dapat didefinisikan sbb:

Dimana, $\mathrm{P}=$ hujan

$$
\text { Input }(P)=P-\text { Eta }-A o+(R-Z)
$$

Eta $=$ evapotranspirasi

Ao = aliran permukaan

$\mathrm{R}-\mathrm{Z} \quad=$ retensi dan penggunaan air

\section{b. Faktor I (I nfiltration)}

Tujuan utama dari kajian faktor I adalah untuk mengetahui jika terdapat jalur lain aliran air pada saat perkolasi baik itu di layer atas batuan karbonat, maupun pada akuifer karst, sehingga :

$$
\text { Infiltrasi (I) = UZ . A. GWR }
$$

UZ = tutupan pada zone tak jenuh

A $\quad=$ karakteristik infiltrasi

GWR = perkolasi dari imbuhan airtanah

Untuk mendefinisikan faktor ini, eksperimen di lapangan terutama adalah pemetaan morfologi lahan, dan mendefinisikan sistem aliran karst yang mungkin harus dilakukan. Yang kedua dapat dilakukan dengan membuat hubungan antara hasil perhitungan infiltrasi, GWR, dan perhitungan debit mataair pada suatu kawasan tangkapan hujan yang diperkirakan. 


\section{Faktor Exfiltrasi (E)}

Exfiltrasi ini sebenarnya adalah suatu nilai yang diperkirakan dapat mewakili sistem aliran air pada suatu daerah tangkapan karst yang didefinisikan sbb:

$$
\text { Exfiltration }(E)=\text { hidrograf aliran . simpanan . waktu tempuh air }
$$

Tentu saja, untuk mendefinisikan faktor E kita butuh data hidrograf sepanjang tahun yang kemudian dipisahkan antara aliran dasar dan aliran langsungnya. Aliran dasar asumsinya adalah air yang berasal dari infiltrasi.

\section{d. Validasi (A)}

Validasi dilakukan untuk mengetahui secara keseluruhan sistem air pada suatu daerah tangkapan dan kembali mendefiniskan nilai-nilai pada faktor I, E, dan P. Pada tahap ini pengukuran lapangan dapat dilakukan yaitu dengan melakukan tracer test (dari zone infiltrasi ke mata air) dan penggunaan bahan isotop.

\section{Metode-metode lainnya}

Metode lain seperti pendefinisian Intrinsic Vulnerability (Ianchu, et al.,2005) dan penggunaan Metode Statis (Matthieu et al., 2005) pada kenyataannya selalu mempunyai faktor pengubah skor kerentanan yang selalu tergantung dari sifat geomorfologi karst terutama kelerengan dan cekungan serta keberadaan lobanglobang yang menghubungkan sistem permukaan dan bawah permukaan

\section{Kesimpulan}

Dari kajian metode-metode untuk mendefinisikan kerentanan kawasan karst terhadap pencemar, dapat secara singkat disimpulkan bahwa pengetahuan tentang geomorfologi karst yang unik merupakan kunci atau pembeda tingkat kerentanan kawasan karst terhadap kemungkinan tercemar oleh polutan. Meskipun, biasanya pengetahuan tentang detail morfologi karst sering diabaikan oleh kalangan yang berkecimpung pada bidang hidrologi karst, terutama yang menggeluti spesifikasi hidrogeokimia karst. Hal ini disebabkan oleh pandangan mereka bahwa komposisi kimia airtanah karst lebih disebabkan dominannya interaksi antara air dan batuan.

Tetapi, dalam kenyataanya, morfologi permukaan kawasan karst akan berpengaruh terhadap sirkulasi sistem air di karst atau dalam kata lain, besar kecilnya komponen airtanah karst (infiltrasi, autogenik, allogenik, recharge langsung, dll) sangat tergantung pada distribusi dan banyak-sedikitnya ponor, sungai yang tertelan, diameter cekungan, doline, polje, dll. Nah, hal inilah yang tampaknya sudah disadari oleh mereka yang mengembangkan metode untuk mendefinisikan kerentanan di daerah karst yang ternyata tidak bisa lepas dari gemorfologi detail permukaan karst.

\section{Referensi}

Alpha, T.R., Galloway,J.P., Tinsley, J.C.,2002, Karst Topography Computer Animations and Paper Model, Open-File Report 97-536-A, .US. Department of The Interior U.S. Geological Survey

Cichoki, G., Zojer, H., 2005, VURAAS-Vulnerability and Risk Analysis in Alpine Aquifer System, In: Water Resources and Environmental Problem in Karst- Proceedings of the International Conf. and Field Seminars Belgrade \& Kotor/Serbia Montenegro, $\mathrm{IAH}$ of Serbia and Montenegro 


\section{Citation: Gunung Sewu, Indonesian Cave and Karst Journal, Vol 2, No 1, April 2006}

Doerfliger, N. and Zwahlen, F. 1998. Practical Guide, Groundwater Vulnerability Mapping in Karstic region (EPIK). Swiss Agency for the Environment, Forests and landscape (SAEFL), Bern, 56 pp.

Doerflinger, N. \& Zwahlen, F. ,1998: P r a x i s h i I f e : K a r t i e r u n g d e r Vulnerabilität in Karstgebieten (Methode EPIK) 56 p.BUWAL, Bern.

Dreybrodt, W.,1988, Process in Karst Systems-Physics, Chemistry, and Geology, Springer-Verlag, Bremen

Ford, D. and Williams, P. 1992. Karst Geomorphology and Hydrology, Chapman and Hall, London

Foster, S.S.D., 1987, Fundamental Concepts in Aquifer Vulnerability, Pollution, Risk and Protection Strategy. In:Vulnerabilty of Soil and Groundwater to Pollutants (ed. by. W. Van Duijvenbooden), 69-86, TNO Commite on Hydrological Research, The Hague, Proceedings and Information no. 38

Gunn, J., 1986, Solute Process and Karst Landform. In:Solute Process (ed. by S.T. Trudgill), 363-437. Wiley, Chickester, UK.

Goldscheider, N., Klute, M., Sturm, S.,Hötzl, H. ,2000: The PI-method - a GIS based approach to mapping groundwater vulnerability with special consideration of karst aquifers. - Z. f. angew.Geol., 46, p. 157-166.

Haryono, E., 2004, Hidup Bersahabat Dengan Kawasan Karst, Publikasi Khusus Forum Karst Goenoeng Sewoe, Yogyakarta

I ianchu, O., Mihai, P., \& Daniel, S., 2005, Intrinsic Vulnerability of Cotetul Dobrestilor Karst Aquifer (Bihor Mountain, Romania), In: Water Resources and Environmental Problem in Karst- Proceedings of the International Conf. and Field Seminars Belgrade \& Kotor/Serbia Montenegro, IAH of Serbia and Montenegro

Leibundgut, C., 1998, Karst Hydrology (Proceedings of Workshop W2), Rabat, Morocco, IAHS Publication no. 247

Matthieu, F., Nicolas, M., Ludivine, D., Michel, B., Joel, R. and Dupont, J., 2005, Characterization of the Transport Properties of Karst Aquifer by Means of Multitable Analysis:The Statis Method, In: Water Resources and Environmental Problem in Karst- Proceedings of the International Conf. and Field Seminars Belgrade \& Kotor/Serbia Montenegro, IAH of Serbia and Montenegro

Plan, P. , Decker, K. \& Faber, R., 2003, Attributed Sinks, a GIS-Tool Quantifying Morphological Vulnerability Parameters in Karstic Catchment Areas, Department of Geological Sciences University of Vienna, Austria

Quinlan, J.F., Smart, P.L.Schindel, G.M., Alexander, E.C.Jr, Edwards, A.J. \& Smith, A.R., 1991, Recommended Administratuve Regulatory Definition of Karst Aquifer, Principles for Classification of Carbonate Aquifers and Practical Evaluation of Vulnerability of Karst Aquifer. In Proceedings of the 3rd Conf. On Hydrogeology, geology and Management of Groundwater in Karst Terrains, 573-635. National Water Well Association, Dublin, Ohio.

Short, N.M., Blair, R.W. 1986. Geomorphology from Space, NASA Publication. http://geoinfo.amu.edu.pl/wpk/geos/GEO_HOME_PAGE.html

Smith, D.I., 1993, The Nature of Karst Aquifer and Their Susceptibility to Pollution. In: Karst Terrains. Environmental Changes and Human Impact (ed. by P. W. Williams), 41-58. Catena Supplement 25, Cremlingen-Desteldt.

Summerfield, M.A., 1991, Global Geomorphology, John Wiley and Sons, New York. 
Citation: Gunung Sewu, Indonesian Cave and Karst Journal, Vol 2, No 1, April 2006

Sweeting, M.M., 1972, Karst Landforms, Macmillan, London.

Trudgil, S., 1985, Limestone Geomorphology, Longman, New York.

White, W.B., 1988. Geomorphology and Hydrology of Karst Terrain. Oxford University Press, New York 